\title{
The Effect of Combination Avocado Juice Administration and Storytelling Therapy on Body Weight in Children with HIV/AIDS
}

\author{
Warsini, Dinar Ariasti \\ Nursing Academy of Panti Kosala, Surakarta, Central Java
}

\section{ABSTRACT}

Background: The incidence of HIV/AIDS is increasing. In 2015 there were 30,935 new cases, 41,250 in 2016 and 33,660 in 2017, where new case findings were also found in children aged less than 4 years and caused child deaths worldwide in 2011 to reach 230,000. At present there is no treatment that can cure the disease, so various efforts are made to support the health and quality of life of sufferers. The purpose of this study was to analyze the effect of providing a combination of avocado juice and storytelling therapy on the weight of a child with HIV / AIDS. Subjects and Method: This was a quasyexperimental with pre-post test design. A sample of 15 children with HIV/AIDS was selected for this study. The dependent variable was body weight. The independent variable was a combination of avocado juice and storytelling therapy.
Weight data was measured using weight scales. Data were analyzed using the Wilcoxon test.

Results: Body weight (kg) after intervention (Mean= 26.17; $\mathrm{SD}=9.30$ ) was slightly greater than before intervention (Mean= 25.30; $\mathrm{SD}=$ 9.16), with $\mathrm{p}=0.002$.

Conclusion: Combination of avocado juice and storytelling therapy increased body weight in children with HIV/AIDS.

Keywords: storytelling therapy, avocado juice, children with HIV/AIDS

\section{Correspondence:}

Warsini. Nursing Academy of Panti Kosala, Surakarta, Central Java. Alamat Instansi Jl. Raya Solo-Baki KM. 4 Gedangan, Grogol, Sukoharjo, Jawa Tengah. Email: warsinimulyono@gmail.com. Mobile: 0816418071

Cite this as:

Warsini, Ariasti D (2020). The Effect of Combination Avocado Juice Administration and Storytelling Therapy on Body Weight in Children with HIV/AIDS. Indones J Med. 05(02): 148-152. https://doi.org/10.26911/theijmed.2020.05.02.09

(F) (-) Indonesian Journal of Medicine is licensed under a Creative Commons cc) AY NC SA Attribution-NonCommercial-ShareAlike 4.0 International License.

\section{BACKGROUND}

This research is motivated by an increasing number of new HIV positive case findings in Indonesia. HIV positive is the phase before the sufferer is declared to have AIDS. After three years in a row (2010-2012) the number of HIV positive sufferers found to be quite stable, the development of the number of cases in 2013 and 2014 again experienced a significant increase (Ministry of Health, Republic of Indonesia, 2015).

The discovery of new cases of HIV in 2016 was 10.146, in 2017 was 10.488 and in 2018 were 10.190 (Ministry of Health, Re- public of Indonesia, 2019). Most cases are in the productive age but the sad fact is the discovery of new cases was also found at the age of less than 4 years, for example in 2017 as many as 901 (Ministry of Health, 2018). As a result of this disease is the death of children in the world in 2013 with age less than 15 years of 190,000 (Ministry of Health, Republic of Indonesia, 2014b).

HIV is a virus that attacks white blood cells and decreases immunity, while AIDS is a collection of disease symptoms that arise due to decreased immunity caused by infection with the HIV virus. As a result, sufferers need 
Warsini et al. / The effects of avocado juice and storytelling therapy

antiretroviral (ARV) treatment, both to reduce the number of HIV viruses so they do not enter the AIDS stage or to prevent opportunistic infections and various other complications (RI Ministry of Health, 2014a).

A fun activity for children is playing. Preliminary survey results at Rumah Lentera which is a shelter for children with HIV / AIDS, found that these children were isolated by their local residents so they were socially isolated. From the health side of these children regularly consume ARV drugs that are given so they tend to get bored and bored with routines that must be passed so that they need therapy to support their growth and development. For this reason, various efforts must be made to support their health, including storytelling therapy and avocado juice. The storytelling method is a good method for children to foster motivation or enthusiasm for life (Kusmiadi et al., 2008). While avocado juice is a traditional medicine that can increase immunity (Septiatin, 2009).

If the body's immunity increases, the child's growth can increase which can be monitored through weight gain. Although it brings many benefits, but the provision of this therapy has never been done in children in the Lantern House. This study aims to determine the effect of giving storytelling and avocado juice therapy on body weight in children with HIV/ AIDS.

\section{SUBJECTS AND METHOD}

\section{Study Design}

This was a quasi-experimental study with pre-post test design. The study was conducted by observing the children weight as a measure of the child's immune status by weighing the chidlren weight before therapy, then giving storytelling and avocado juice therapy according to the schedule for 1 (one) month. Weight measurements are carried out every Sunday according to their schedule. After the therapy is complete, the body weight is measured again to determine the child's immune status after the therapy is given.

\section{Population dan Sample}

The population of this research was 15 children with HIV / AIDS in the Surakarta City Lentera Foundation. Given the small population, the author took all the children to be used as study samples so that they used total sampling.

\section{Study Variables}

The dependent variable was body weight of children with HIV/ AIDS. The independent variable was the administration of avocado juice and storytelling therapy.

\section{Operational Definition of Variables} Giving storytelling therapy and avocado juice was an intervention carried out by giving storytelling and avocado juice to respondents every day intermittently for one month. Meanwhile, body weight is the result of the measurement of the respondent's body mass measured using weight scales.

\section{Study Instruments}

The instrument used was an observation sheet to determine the administration of storytelling and avocado juice therapy and weight scales to determine the children weight as an indicator of the children immunity status.

\section{Data Analysis}

The collected data was then analyzed using the Wilcoxon test.

\section{Research Ethic}

This research was conducted after obtaining ethical eligibility from the ethics committee of health research from RSUD Dr. Moewardi/ Faculty of Medicine, Universitas Sebelas Maret, No. 56oIV / HREC / 2019

\section{RESULTS}

\section{A.Sample Characteristics}

Table 1 showed sample characteristics. Table 1 showed that half of sample were children aged $\geq 10$ years old (53.33\%). 
Warsini et al. / The effects of avocado juice and storytelling therapy

Table 1. Sample Characteristics

\begin{tabular}{lcc}
\hline \multicolumn{1}{c}{ Characteristics } & $\mathbf{n}$ & \% \\
\hline Age (years) & & 46.67 \\
$<10$ & 7 & 53.33 \\
$\geq 10$ & 8 & \\
Weight before intervention: & & 53.33 \\
$<23 \mathrm{~kg}$ & 8 & 46.67 \\
$\geq 23 \mathrm{~kg}$ & 7 & \\
Weight after intervention: & & 60.00 \\
$<26 \mathrm{~kg}$ & 9 & 40.00 \\
$\geq 26 \mathrm{~kg}$ & 6 & \\
\hline
\end{tabular}

Tabel 2. The Results of Wilcoxon Test

\begin{tabular}{lcccc}
\hline Body weight & n & Mean & SD & p \\
\hline Weight before intervention $(\mathrm{kg})$ & 15 & 25.30 & 9.161 & \multirow{2}{*}{0.002} \\
Weight after intervention $(\mathrm{kg})$ & 15 & 26.17 & 9.304 & \\
\hline
\end{tabular}

\section{B. Bivariate analysis}

Based on Table 2, it was known that body weight (kg) after intervention (Mean= 26.17; $\mathrm{SD}=9.30$ ) was slightly greater than before intervention $(\mathrm{Mean}=25.30 ; \mathrm{SD}=9.16)$, with $\mathrm{p}=0.002$.

\section{DISCUSSION}

The results showed that body weight $(\mathrm{kg})$ after the intervention (Mean=26.17; $\mathrm{S}=9.30$ ) was slightly greater than weight $(\mathrm{kg})$ before the intervention (Mean=25.30; $\mathrm{SD}=9.16)$. Although there is an average weight gain, the effect of intervention in increasing body weight is very weak. So that the provision of storytelling and avocado juice therapy has not been effective enough to increase body weight as an indicator of the immune status of children with HIV / AIDS.

Weight is one indicator of the adequacy of children's nutrition. The results of the study stated that children with HIV will experience a decrease in the immune system (Fitriani et al., 2013). One of the factors that influence the condition of malnutrition is impaired immune function so that in HIV sufferers the condition of nutritional status will decrease and accelerate the progression of HIV to AIDS. The provision of adequate nut- rition is very important for people with HIV / AIDS because this disease causes a lot of meta-bolism disturbance so it requires high quality energy and protein and other nutrients (Nnyepi et al., 2015). As an indicator of nutritional status, an increase in body weight can be sought by increasing the intake of nutrients such as carbohydrates, proteins and adequate fats (Setyarahma et al., 2016). In this study respondents were given avocado juice where the avocado is a fruit that has a high fat content and the majority consists of unsaturated fatty acids (Septiatin, 2009).

High fat consumption can cause the fastest weight gain because it has more calories compared to carbohydrates or protein so that the respondent's weight can increase. Avocados also contain oleic and linoleic fatty acids which are antioxidants, contain pro vitamin $A$, vitamin $C$, vitamin $E$ and vitamin $\mathrm{B}$ as well as minerals iron, copper, magnesium and potassium (potassium) which are needed in helping the regeneration of blood cells so it is needed by the body.

In addition to adequate nutrition, there are also other factors that can affect immunity, namely social support. With good social support will affect the quality of life of people with HIV / AIDS because it can reduce the in- 
Warsini et al. / The effects of avocado juice and storytelling therapy

cidence of depression. The results of the study indicate that with good social support in patients with HIV / AIDS will reduce the occurrence of depression (Alemu et al., 2012). This is important because the approach to health is not only based on physiological, biological or genetic factors to produce behavioral changes to improve quality of life. In this study the respondents' isolated residence in the burial area made storytelling one of the options for inviting children to socialize and as a form of social support (Gray et al., 2015). Storytelling can change the risk of health behavior because storytelling can develop fantasy, empathy and various other types of feelings and foster interest in reading and build closeness and harmony, as well as foster motivation or enthusiasm for life (Kusmiadi et al., 2008). The results of the study also suggest that storytelling can be designed as a medium to convey positive messages related to HIV / AIDS (Makalela, 2015). With a high spirit of life, children with HIV / AIDS will be easily directed to behave in a life that supports health. So that the combination of storytelling therapy and avocado juice can improve immunity when viewed from weight indicators.

The results of the analysis showed that the strength of the effect of giving storytelling and avocado juice therapy to immunity seen from body weight calculated through the Effect Size using the Cohen formula and the results obtained Cohen's $\mathrm{d}=0.094$, so that it can be interpreted the effect strength is weak. This is due to many other factors that can influence immunity in terms of body weight, such as energy intake, protein intake and other quality nutrients (Setyarahma et al., 2016). Besides psychological factors sufferers must also be considered because HIV / AIDS causes stigma that negatively affects the sufferer. This is reinforced by the results of research that mentions many conditions that also influence the problem of immunity re- lated to nutrition including economic problems, health services, education, knowledge and income (Duggal et al., 2012).

\section{AUTHOR CONTRIBUTION}

Warsini takes care of licensing, compiles research methodology and retrieves study data. Dinar Ariasti took data, analyzed the data and interpreted the results of the study.

\section{CONFLICT OF INTEREST}

There is no conflict of interest in this study.

\section{FUNDING AND SPONSORSHIP}

This research was funded by the Directorate of Research and Community Service, Ministry of Research and Technology.

\section{ACKNOWLEDGEMENT}

The researcher would like to thank the Director of the Directorate of Research and Community Service at the Ministry of Research and Technology, Director of the Surakarta Panti Kosala nursing academy, and Chairperson of the LPP Panti Kosala nursing academy, Surakarta, and Chairperson of the LENTERA Foundation, Surakarta.

\section{REFERENCE}

Alemu H, Mariam DH, Tsui A, Ahmed S, Shewamare A (2012). Effect of depressive symptoms and social support on weight and CD4 count increase at HIV clinic in Ethiopia. AIDS Care, 24(7): 866-877. https://doi.org.10.1080/09540121.2011.648160

Duggal S, Chugh T, Duggal AK (2012). HIV and Malnutrition: Effects on Immune System. Clin Dev Immunol, 1-8. https://doi.org. 10.1155/2012/784740.

Fitriani D, Nadhiroh SR, Triyono EA (2013). Correlations between nutritional status changes with number of $\mathrm{CD} 4$ cell changes in HIV/AIDS Patients. Folia Medica Indonesiana, 49(3): 155-162. 
Warsini et al. / The effects of avocado juice and storytelling therapy

Gray B, Young A, Blomfield T (2015). Altered lives: assessing the effectiveness of digital storytelling as a form of communication design. 29(4): 635-649. https://doi.org/10.1080/10304312.2015.102 5359

Ministry of Health Republic of Indonesia (2014a). Pedoman Penerapan Terapi HIV pada Anak (Guidelines for the Application of HIV Therapy in Children). Jakarta: Kemenkes.

Ministry of Health Republic of Indonesia (2014b) Situasi dan Analisis HIV AIDS (HIV AIDS Situation and Analysis).pdf. Jakarta: Kemenkes.

Ministry of Health Republic of Indonesia RI (2015). Profil Kesehatan Indonesia 2014 (Indonesia Health Profile 2014). Jakarta: Kemenkes.

Ministry of Health Republic of Indonesia (2018). Data dan Informasi Profil Kesehatan Indonesia 2017 (Indonesia Health Profile Data and Information 2017). Jakarta: Kemenkes.

Ministry of Health Republic of Indonesia RI (2019). Data dan Informasi Profil Kesehatan Indonesia 2018 (Indonesia Health Profile Data and Information 2018). Jakarta: Kemenkes.

Kusmiadi A, Sriwahyuningsih, Nurfalah Y
(2008). Strategi Pembelajaran PAUD Melalui Metode Dongeng Bagi Pendidik PAUD (PAUD Learning Strategies Through Storytelling Methods For PAUD Educators). Jurnal Ilmiah VISI PTKPNF, 3(2).

Makalela L (2015). Narrative interpretation of HIV/AIDS messages: The effects of storytelling prompts among rural university students. 29(3): 400-418. https://doi.org/10.1080/02560046.2015.1059555 .

Nnyepi M, Bennink MR, Jackson-Malete J, Venkatesh S, Malete L, Mokgatlhe L, Weatherspoon LJ (2015). Nutrition status of HIV + children in Botswana. 115(5): 495-514. https://doi.org/ 10.1108/HE-04-2014-0052.

Septiatin E (2009). Apotek Hidup dari Tanaman Buah (Life Pharmacy from Fruit Plants). Yogyakarta: Yrama Widya.

Setyarahma AF, Kartasurya MI, Aruben R (2016). Hubungan asupan Makanan dengan Penambahan Berat Badan pada Remaja Hamil Usia 15-19 Tahun (The relationship of food intake with weight gain in pregnant adolescents aged 15-19 years). Jurnal Kesehatan asyarakat, 4: 158-167. Available at: http://ejournals1.undip.ac.id/indek.php/jkm. 